\title{
Occupational rhinoconjunctivitis to cyclamen: A case report
}

\author{
Rinoconjuntivite ocupacional a cyclamen - Caso clínico
}

Cristiana Sofia Ferreira' ${ }^{1}$, José Ferreira1 ${ }^{1}$, Bartolomé Borja², Arminda Guilherme ${ }^{1}$

\section{ABSTRACT}

Cyclamen is a plant belonging to the Primulaceae family, widely used as an indoor ornamental flowering plant. Occupational allergy to cyclamen has been occasionally described in the current literature. The authors intend to report the case and diagnostic approach of a suspected occupational cyclamen allergy.

Keywords: Rhinitis, allergy, cyclamen, occupational exposure.

\section{Introduction}

Cyclamen is a plant belonging to the Primulaceae family, widely used as an indoor ornamental flowering plant. Occupational allergy to cyclamen has been occasionally described in the current literature. The authors intend to report the case and diagnostic approach of a suspected occupational cyclamen allergy.

\section{Case report}

A 55-year-old woman with an atopic history was referred to our allergy department for work-related rhinoconjunctivitis. She had been working as a flower cultivator in floral industry with various kinds of flowers for the past 16 years. During the past 7 years, she had developed nasal obstruction, rhinorrhea, sneezing, and itching. Symptoms occurred from autumn to spring, mainly during cyclamen blooming season,

\section{RESUMO}

O ciclame é uma planta pertencente à família Primulaceae, amplamente utilizada como planta ornamental de interior. A alergia ocupacional ao ciclame raramente foi descrita na literatura. Os autores pretendem descrever um caso e abordagem diagnóstica de uma suspeita de alergia ocupacional ao ciclame.

Descritores: Rinite, alergia, ciclame, exposição ocupacional.

and improved over weekends and holidays. Physical examination revealed swollen, pale nasal mucosa and turbinates, but it was otherwise unremarkable. Skin prick tests with a standard panel of inhalant allergens (tree and grass pollen, house dust mites, dog and cat dander, and molds) were positive for grass pollen, Cynodon dactylon, mugwort pollen, plane tree pollen, birch pollen (Roxall ${ }^{\circledR}$, Spain), and Alternaria alternata. Prick-by-prick tests to cyclamen pollen, petal, and leaf showed positive results to pollen $(15 \times 13 \mathrm{~mm})$. Tests with the same allergens were performed in two control subjects, with negative results. Basic pulmonary function testing (spirometry) was performed, with normal results (forced expiratory volume in one second $>80 \%$ ).

Protein extracts from cyclamen leaf, flower, and pollen were prepared by delipidization, homogenization

1. Centro Hospitalar Vila Nova de Gaia/Espinho, EPE, Allergy and Clinical Immunology Department - Porto, Porto, Portugal.

2. R\&D Department, Roxall - Bilbao, Bilbao, Espanha. 
in phosphate-buffered saline (15\% W/V) $(50 \mathrm{mM}$ phosphate buffer, $100 \mathrm{mM} \mathrm{NaCl}, \mathrm{pH} 7.5)$, dialyzation against distilled water, and lyophilization. Serum total immunoglobulin E (IgE) was $3037 \mathrm{kU} / \mathrm{L}$, and specific IgE (ImmunoCAP, ThermoFisher Scientific, Phadia AB, Uppsala, Sweden) was $12.1 \mathrm{kUA} / \mathrm{L}$ against grass pollen, $7.35 \mathrm{kUA} / \mathrm{L}$ against $C$. dactylon pollen, $35.7 \mathrm{kUA} / \mathrm{L}$ against mugwort pollen, $6.77 \mathrm{kUA} / \mathrm{L}$ against birch pollen, and $11.6 \mathrm{kUA} / \mathrm{L}$ against plane tree pollen.

Sodium dodecyl sulphate-polyacrylamide gel electrophoresis (SDS-PAGE) and immunoblotting were performed in reducing conditions (with 2-mercaptoethanol) as described by Laemmli', with cyclamen extracts from leaf, flower, and pollen. The immunoblot assay revealed an intense IgE-binding band with molecular mass $<14 \mathrm{kDa}$ in the three samples. Furthermore, another IgE-reactive band of $48 \mathrm{kDa}$ was detected in cyclamen leaf, and some weaker bands of $66 \mathrm{kDa}, 45 \mathrm{kDa}, 40 \mathrm{kDa}, 23 \mathrm{kDa}$, $18.5 \mathrm{kDa}$, and $17 \mathrm{kDa}$ were observed in cyclamen pollen. No bands were detected with control serum (pool of sera from non-atopic subjects). Specific IgE against Pru p 3 (peach nsLTP) analyzed by ImmunoCAP was positive.

\section{Discussion}

Occupational allergy due to decorative flowers in the floral industry has been rarely described, especially in case reports. The diagnostic process of flower allergy is difficult in many cases, as standardized allergenic extracts for skin prick or serum specific $\lg$ E determination are unavailable. The sensitivity and specificity of prick-by-prick tests with flowers are unknown. However, in most cases of occupational allergy caused by ornamental flowers, unstandardized extracts for skin prick or prick-by-prick tests have been used to demonstrate specific sensitization. ${ }^{2-5}$ The use of native plant tests has been recommended for screening for flower allergy. ${ }^{2}$

Only two case reports of cyclamen occupational allergy have been described: one case of a floriculturist family in Holland whose mother and daughter developed asthma and rhinoconjunctivitis allergy, respectively, to cyclamen pollen, and another of a floriculturist in Italy. ${ }^{6,7}$

Our study confirmed a diagnosis of occupational rhinoconjunctivitis caused by cyclamen. In our patient, the diagnosis of IgE-mediated sensitization to cyclamen was demonstrated by a positive prick-by-prick test to cyclamen pollen and detection of IgE-reactive proteins. The in vitro SDS-PAGE immunoblotting assay revealed in leaf, flower, and pollen extracts several protein bands ranging between $66 \mathrm{kDa}$ to $17 \mathrm{kDa}$, with a more intense band with molecular mass < $14 \mathrm{kDa}$. This protein was not identified, but its molecular mass matched the one from the nsLTP family, proteins that have been associated with sensitization by inhalation in several cases of occupational allergy, as allergy to flowers, peach leaf, fruits, and cereal flours. ${ }^{1,8-10}$ The profile of molecular mass of the other IgE-reactive bands detected partially match those described by Ariano et al. ${ }^{7}$

Our report is hampered by the absence of a specific nasal challenge to cyclamen extracts. The required conditions to perform a specific nasal challenge were not available, and the patient was effectively avoiding allergen exposure and refused to be re-exposed.

Chronic exposure in occupational settings may cause de novo sensitization through inhalation of cyclamen proteins with an IgE-dependent mechanism. We detected cyclamen IgE-reactive proteins in an SDS-PAGE immunoblotting assay. Based on the results obtained, and to our knowledge, this is the first patient with a sensitization pattern that differs from those described before. The patient was completely removed from exposure to cyclamen and changed her job position after being diagnosed with occupational allergy, and now she has no symptoms.

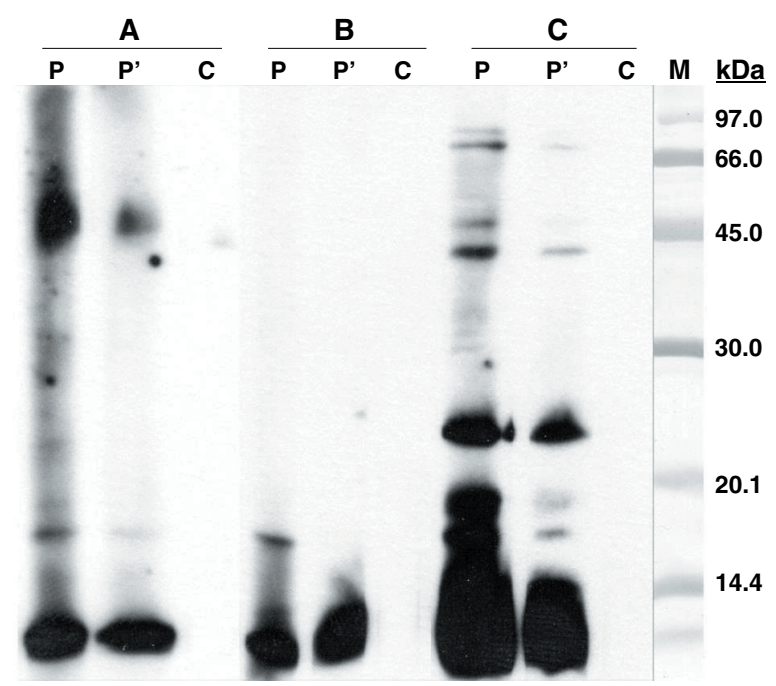

Figure 1

SDS-PAGE Immunoblotting. A) Cyclamen leaf extract; B) Cyclamen flower extract; C) Cyclamen pollen extract. Lane $P, P^{\prime}$ : patient serum. Two dilution. Lane C: control serum (pool of sera from non atopic subjects), Lane M: Molecular mass marker 


\section{References}

1. Laemmli U. Cleavage of structural proteins during the assembly of the head of bacteriophage T4. Nature. 1970;227(5259):680-5.

2. Jong W, Vermeulen M, Wijk G, Groot H. Occupational allergy caused by flowers. Allergy. 1998;53:204-9.

3. Herrera-Lasso V, Dalmau G, Gázquez V, Pineda Losa F, Castillo Fernández M , Garnica D, et al. Allergy to Spathiphyllum wallisii, an Indoor Allergen. J Investig Allergol Clin Immunol. 2019;29(6):451-71.

4. Kanerva L, Makinen-Kiljunen S, Kiistala R, Granlund H. Occupational allergy caused by spathe flower (Spathiphyllum wallisii). Allergy. 1995;50:174-8

5. Jansen AP, Visser FJ, Nierop G, de Jong NW, Waandersde Lijster de Raadt J, Vermeulen A, et al. Occupational asthma to amarylis. Allergy. 1996;51(11):847-9.

6. Bolhaar P, Van Ginkel W. Occupational allergy to Cyclamen. Allergy. 2000;55:418-9.

7. Ariano R, Mistrello G, Panzani RC. Occupational respiratory allergy to cyclamen pollen: A case report. Eur Ann Allergy Clin Immunol. 2006;38(3):90-3.
8. Mencía G, Morales C, Peláez A, Reig M, Vicario S, Bartolomé B. Rinoconjuntivitis ocupacional por Lilium stargazer. XXVI Congreso Nacional de la SEAIC. J Investig Allergol Clin Immunol. 2018(suppl.3):192-3.

9. Pérez-Calderón R, Gonzalo-Garijo A, Rodríguez-Velasco F, Sánchez-vega S, Bartolomé B. Occupational respiratory allergy in peach crop workers. Allergy. 2017;72(10):1556-64.

10. Palacin A, Quirce S, Armentia A, Fernández-Nieto M, Pacios LF, Asensio T, et al. Wheat lipid transfer protein is a major allergen associated with baker's asthma. Allergy Clin Immunol. 2007;120(5):1132-8.

No conflicts of interest declared concerning the publication of this article.

Corresponding author:

Cristiana Sofia Ferreira

E-mail: cristianascferreira@gmail.com 